Chester, M., R. S. Cowan, M. F. FAy and T. C. Rich (2007): Parentage of endemic Sorbus L. (Rosaceae) species in the British Isles: evidence from plastid DNA. Botanical Journal of the Linnean Society 154: 291-304.

Demesure, B., B. L. Guerroue, G. Lucchi, D. Part and R. J. PETIT (2000): Genetic variability of a scattered temperate forest tree: Sorbus torminalis L. Ann. For. Sci. 57: 63-71.

DewAY, D. R. and K. H. LU (1959): A correlation and path coefficient analysis of components of crested wheat grass seed production. Agronomy Journal 51: 515-518.

FALCONER, D. S. and T. F. C. MACKAY (1996): Introduction to quantitative genetics. Longman, London.

Hoebee, S. E., C. Menn, P. Rotach, R. Finkeldey and R. HolderegGer (2006): Spatial genetic structure of Sorbus torminalis: The extent of clonal reproduction in natural stands of a rare tree species with a scattered distribution. Forest Ecology and Management 226: 1-8.

KuMAR, A. (2007). Growth performance and variability in different clones of Gmelina arborea (Roxb). Silvae Genetica 56: 32-36.

MACAllister, M. (2005): The genus Sorbus: mountain ash and other rowans. Royal Botanical Garden, Kew.

Pedersen, A. P., J. K. Hansen, J. M. Mtika and T. H. MsANGI (2007): Growth, stem quality and age-age correlations in a teak provenance trial in Tanzania. Silvae Genetica 56: 142-148.
RASPE, O. and J. R. KoHN (2007). Population structure at the S-locus of Sorbus aucuparia L. (Rosaceae: Maloideae). Molecular Ecology 16: 1315-1325.

SÆBØ, A. and Ø. JoHnSEN (2000): Growth and morphology differ between wind-exposed families of Sorbus aucuparia (L.). J Arboric 26: 255-262.

Saleem, U., I. Khaliq, T. Mahmood and M. Rafique (2006): Phenotypic and genotypic correlation coefficients between yield and yield components in wheat. Journal of Agricultural Reaserch 44: 1-6.

SAS Institute (1989): SAS user's guide: statistics. $5^{\text {th }}$ edition. SAS Institute, NE.956 p.

Sebbenn, A. M., A. A. S. Pontinha, E. Giannotti and P. Y. KAGEYAMA (2003): Genetic variation in provenance-progeny test of Araucari angustifolia (Bert.) O. Ktze. In Sao Paulo, Brazil. Silvae Genetica 52: 181-184.

SOKAL, R. R. and F. J. RoHLF (1995): Biometry: the principles and practice of statistics in biological research. $3^{\text {rd }}$ edition. W. H. Freeman and Co., San Francisco, California. $859 \mathrm{p}$.

SPERENS, U. (1997): Long-term variation in, and effects of fertilizer addition on, flower, fruit and seed production in the tree Sorbus aucuparia (Rosaceae). Ecography 20: 521-534.

Termentzi, A., P. Kefalas and E. Kokkalou (2006): Antioxidant activities of various extracts and fractions of Sorbus domestica fruits at different maturity stages. Food Chemistry 98: 599-608.

\title{
Genetic Variation in Two Rare Endemic Mexican Trees, Magnolia sharpii and Magnolia schiedeana
}

\author{
By A. C. Newton ${ }^{1,2), 8)}$, J. Gow ${ }^{1,5)}$, A. Robertson ${ }^{1,6)}$, G. Williams-Linera ${ }^{3)}$, N. Ramírez-Marcial ${ }^{4)}$, \\ M. GonzÁlez-Espinosa ${ }^{4)}$, T. R. AllnutT ${ }^{1), 7)}$ and R. Ennos ${ }^{1)}$
}

(Received $25^{\text {th }}$ October 2007)

\begin{abstract}
Patterns of genetic variation were examined within two endemic tree species restricted to Mexican cloud forest, Magnolia sharpii and Magnolia schiedeana. Leaf samples collected from natural populations were analysed using PCR RFLP of cpDNA, Inter-SSR and isozyme genetic markers, which were used to test a series of hypotheses regarding patterns of intraspecific variation within the two species. Genetic diversity esti-

\footnotetext{
${ }^{1)}$ Institute of Ecology and Resource Management, University of Edinburgh, Darwin Building, Kings Buildings, Mayfield Rd., Edinburgh, EH9 3JU.

2) School of Conservation Sciences, Bournemouth University, Talbot Campus, Poole, Dorset BH12 5BB, UK.

3) Instituto de Ecologia A.C., Apartado Postal 63, Xalapa, Veracruz 91000, Mexico.

4) Departamento de Ecología y Sistemática Terrestres, División de Conservación de la Biodiversidad, El Colegio de la Frontera Sur (ECOSUR), Apartado Postal 63, 29200 San Cristóbal de Las Casas, Chiapas, México.
}

mates derived from Inter-SSR markers (mean $\mathrm{S}_{\text {pop }}$ of 0.56 and 0.50 for $M$. sharpii and $M$. schiedeana respectively) are comparable to values obtained for other tree species. As predicted on the basis of its larger geographic range, the degree of population differentiation was found to be higher within $M$. schiedeana than M. sharpii, with $12.9 \%$ and $3.4 \%$ of total variation recorded between populations for the two species respectively using isozymes, and $26 \%$ and $11 \%$ using InterSSR markers. Isozyme analyses indicated negative $\mathrm{F}_{\text {is }}$

5) Present address: Department of Zoology, University of British Columbia, 6270 University Boulevard, Vancouver, B.C., Canada V6T $1 Z 4$.

$\left.{ }^{6}\right)$ Present address: Department of Plant Sciences, University of Oxford, South Parks Road, Oxford OX1 3RB, UK.

$\left.{ }^{7}\right)$ Present address: Central Science Laboratory, Sand Hutton, York, YO41 1LZ, UK.

8) Corresponding author: Dr. AdRIAN NEWTON, School of Conservation Sciences, Bournemouth University, Talbot Campus, Poole, Dorset BH12 5BB, UK. Tel: +44 (0) 1202 595670, Fax: +44 (0) 1202 595255, E-mail: anewton@bournemouth.ac.uk 
values, which may be suggestive of inbreeding in populations of $M$. sharpii, but provided less evidence of inbreeding in $M$. schiedeana. On the basis of PCR RFLP analysis of cpDNA, two chloroplast types were differentiated, type A being recorded for all of the individuals of both species, with the exception of one population of $M$. schiedeana that was fixed for type B. These results are consistent with recent evidence suggesting that some endemic plant taxa are able to maintain relatively high diversity within populations despite the occurrence of inbreeding and genetic drift, and that species with wider geographic ranges tend to exhibit relatively high genetic differentiation among populations. Conservation strategies for these species need to take into account the significant genetic differences recorded among the populations studied.

Key words: cloud forest, conservation biology, genetic variation, isozyme, cpDNA, PCR-RFLP, Magnolia sharpii, Magnolia schiedeana.

\section{Introduction}

The objectives of the present investigation were to examine patterns of genetic variation within two threatened tree species endemic to Mexico, Magnolia sharpii Miranda and Magnolia schiedeana Schltdl. The genus Magnolia has a complex biogeographic history, belonging as it does to one of the oldest extant angiosperm families (Magnoliaceae) (DANDY, 1971). Magnolia is now distributed primarily in Asia (Nepal to New Guinea) and the Americas (E. Canada to Brazil and the Caribbean) (Frodin and GovaERTs, 1996). Both species considered here belong to section Theorhodon Spach., which based on Miocene fossil records, is thought to have contracted drastically in range over the last 25 million years owing to climatic change. A once continuous distribution that extended over much of Miocene USA and into Canada, Mexico and Central America has now been reduced to a highly disjunct distribution in SE USA, Mexico and Central America (FIGLAR, 1993).

A recent taxonomic revision of the Mexican and Central American species has resulted in the description of a number of new taxa (VÁZQUEZ, 1994), but as a group these trees are very poorly known (CALLAWAY, 1994). Following this revision, $M$. schiedeana now has a much smaller range than previously thought; it is apparently restricted to fourteen scattered populations ranging across the Mexican states of Querétaro, Hidalgo, Veracruz, Guerrero and Oaxaca (VÁZqUEZ, 1994). Populations typically occur on steep slopes or ravines in cloud forests at altitudes of 1500-2000 m (DIERINGER and EsPinOSA, 1994). M. sharpii, considered to be one of the most primitive species within the section, is endemic to the Mexican state of Chiapas (VÁZQUEZ, 1994), occurring at only five sites in evergreen cloud forests of the central highlands between elevations of 1950-2940 m (CALLAWAY, 1994). Both $M$. schiedeana and $M$. sharpii are considered as Endangered according to the IUCN Red List of Magnoliaceae (CiCUZZA et al., 2007).

The habitats of both of these species have been severely reduced in recent decades as a result of clearance for agriculture. Analysis of Landsat MSS satellite images supported by interpretation of aerial photography has indicated that the montane forests of Chiapas have been severely fragmented over the past 30 years (CAYUELA et $a l ., 2006)$, which has been accompanied by loss of floristic diversity (GoNZÁLEZ-EsPINOSA et al., 1991, 1995; GALINDO-JAimes et al., 2002). Similarly, in the state of Veracruz establishment of croplands, cattle ranching and the cutting of trees for fuelwood have been important causes of forest destruction, which severely threatens remaining forest fragments and their associated biodiversity (WILLIAMS-LINERA, 2002). M. schiedeana is used for medicinal purposes; for example a decoction of the flowers is used as a remedy for scorpion stings (CALlawaY, 1994). Leaves of $M$. sharpii are used for wrapping tamales (a foodstuff); its timber was used to construct rifles during the Mexican revolution (M. MARTINEZ-ICó, pers. comm.).

Both species are evergreen trees reaching up to thirty meters in height (CALLAWAY, 1994). Very little is known about their ecology. M. schiedeana is known to be similar to most other members of the Magnoliaceae in being self-compatible and beetle pollinated (DIERINGER and ESPINOSA, 1994), although it seems to possess a more specialised pollination system than temperate Magnolias. One of its two known pollinators, Cyclocephala jalapensis, is a regionally endemic scarab beetle that appears to be dependent on $M$. schiedeana for adult nutrition and reproduction (DIERINGER and DELGADO, 1994). All $M$. schiedeana populations studied by DIERINGER and EsPINOSA (1994) exhibited very low fertility, which was attributed to previous episodes of overharvesting. In Chiapas, forest fragmentation and habitat modification of the remaining forest fragments appear to be limiting conditions for many understory trees, including $M$. sharpii (GonZÁlEZ-EsPINOSA et al., 1991; RAMíREZ-MARCIAL et al., 2001).

The research was designed to test a series of hypotheses relating to the pattern of intraspecific variation within the two species. Specifically, given their contrasting patterns of distribution, and the fact that both species are restricted to relatively small forest fragments, based on current theory and empirical evidence from other species (NYBOM and BARTISH, 2000; HAMRICK et al., 1992) we hypothesized that: (i) M. schiedeana maintains higher genetic variation within its populations compared with $M$. sharpii because of its wider geographic range; (ii) given their animal-pollinated breeding system, these species display relatively low intraspecific variation, but high population differentiation, compared with wind-pollinated tree species; (iii) higher within-population variation is expected within larger populations of both species; and (iv) geographically isolated populations are expected to be characterised by a relatively high degree of population differentiation. These hypotheses were tested using a variety of different genetic markers: PCR RFLP of cpDNA, inter-SSRs and isozymes.

\section{Materials and Methods}

\section{Sample collection}

The collection of material for analysis was limited by the rarity and restricted geographical ranges of the species under study. In the case of $M$. sharpii, samples 
were collected from four out of the five sites in which the species is known to occur; the remaining site was not visited because of its inaccessibility (Table 1, Figure 1). In the case of $M$. schiedeana, samples were collected from each of the three populations known to exist in the vicinity of Xalapa, Veracruz (Table 1, Figure 1). These populations are isolated by substantial distances ( $>100$ $\mathrm{km}$ ) from any other populations of the species, and form a cluster at a similar geographic scale to those of $M$. sharpii, facilitating comparison of the two species. Of the $M$. sharpii sample sites, sites 1-3 are clustered within less than $15 \mathrm{~km}$ of each other, while site 4 is located at a distance of 55-70 km from sites 1-3 (Figure 1 ). The three $M$. schiedeana populations are located within $25 \mathrm{~km}$ of each other: site 6 is located within 25 $\mathrm{km}$ of site 7 , and site 5 is located within $10 \mathrm{~km}$ and 20 $\mathrm{km}$ of sites 6 and 7, respectively (Figure 1). The location of each site was recorded using a hand-held GPS receiv- er (Silva, Livingston, UK) and altitude was recorded using a digital altimeter.

Samples were collected throughout the entire area of a site using a minimum distance between trees of $10 \mathrm{~m}$ to reduce the probability of sampling the same individual more than once. In each case, as many individuals were sampled as possible, which resulted in variation in sample size between sites (Table 1). Leaf material was collected from each individual sampled. Material for DNA analysis was dried and preserved in labelled, sealable plastic bags containing silica gel (S4883 silica, Sigma Chemical Company Ltd, Fancy Road, Dorset, UK) and stored at $4{ }^{\circ} \mathrm{C}$ prior to DNA extraction. For isozyme analysis, fresh leaf and bud material was placed in loosely sealed, 'Stayfresh longer' bags (Lakeland Limited, Windermere, Cumbria, UK) and stored in a refrigerator at $4{ }^{\circ} \mathrm{C}$ before isozyme extraction was carried out. DNA extractions were conducted according to a modified

Table 1. - Location and characteristics of (A) Magnolia sharpii and (B) Magnolia schiedeana populations sampled for analysis.

\begin{tabular}{|c|c|c|c|c|c|c|}
\hline & $\mathrm{A}$ & & & & & \\
\hline $\begin{array}{l}\text { Site } \\
\text { no. }\end{array}$ & Site name & $\begin{array}{l}\text { Altitude } \\
\text { (m) }\end{array}$ & $\begin{array}{l}\text { Geographical } \\
\text { coordinates } \\
\text { (lat., long.) }\end{array}$ & $\begin{array}{l}\text { Approx. } \\
\text { area of } \\
\text { population } \\
\text { (ha) }\end{array}$ & $\begin{array}{l}\text { No. } \\
\text { sampled } \\
\text { for Inter- } \\
\text { SSR } \\
\text { analysis }\end{array}$ & $\begin{array}{l}\text { No. sampled } \\
\text { for isozyme } \\
\text { analysis }\end{array}$ \\
\hline 1 & $\begin{array}{l}\text { Merced- } \\
\text { Bazom }\end{array}$ & 2490 & $\begin{array}{l}16^{\circ} 44^{\prime} 72^{\prime \prime} \mathrm{N}, \\
92^{\circ} 28^{\prime} 58^{\prime \prime} \mathrm{W}\end{array}$ & 15 & 16 & 36 \\
\hline 2 & Achlum & 2400 & $\begin{array}{l}16^{\circ} 46^{\prime} 58^{\prime \prime} \mathrm{N} \\
92^{\circ} 27^{\prime} 25^{\prime \prime} \mathrm{W}\end{array}$ & 4 & 23 & 52 \\
\hline 3 & E1 Retiro & 2070 & $\begin{array}{l}16^{\circ} 49^{\prime} 11^{\prime \prime} \mathrm{N} \\
92^{\circ} 29^{\prime} 111^{\prime \prime} \mathrm{W}\end{array}$ & 15 & 24 & 51 \\
\hline 4 & $\begin{array}{l}\mathrm{La} \\
\text { Yerbabuena }\end{array}$ & 2120 & $\begin{array}{l}17^{\circ} 11^{\prime} 50^{\prime \prime} \mathrm{N} \\
92^{\circ} 53^{\prime} 79^{\prime \prime} \mathrm{W}\end{array}$ & 150 & 17 & 29 \\
\hline
\end{tabular}

\begin{tabular}{|c|c|c|c|c|c|c|}
\hline $\begin{array}{l}\text { Site } \\
\text { no. }\end{array}$ & Site name & $\begin{array}{l}\text { Altitude } \\
\text { (m) }\end{array}$ & $\begin{array}{l}\text { Geographical } \\
\text { coordinates } \\
\text { (lat., long.) }\end{array}$ & $\begin{array}{l}\text { Approx. } \\
\text { area of } \\
\text { population } \\
\text { (ha) }\end{array}$ & $\begin{array}{l}\text { No. } \\
\text { sampled } \\
\text { for Inter- } \\
\text { SSR } \\
\text { analysis }\end{array}$ & $\begin{array}{l}\text { No. sampled } \\
\text { for isozyme } \\
\text { analysis }\end{array}$ \\
\hline 5 & Banderilla & 1520 & $\begin{array}{l}19^{\circ} 34^{\prime} 97^{\prime \prime} \mathrm{N}, \\
96^{\circ} 56^{\prime} 80^{\prime \prime} \mathrm{W}\end{array}$ & 5 & 22 & 54 \\
\hline 6 & Acajete & 1950 & $\begin{array}{l}19^{\circ} 33^{\prime} 61^{\prime \prime} \mathrm{N}, \\
97^{\circ} 01^{\prime} 05^{\prime \prime} \mathrm{W}\end{array}$ & 15 & 20 & 54 \\
\hline 7 & Acatlán & 1810 & $\begin{array}{l}19^{\circ} 40^{\prime} 78^{\prime \prime} \mathrm{N} \\
96^{\circ} 51^{\prime} 20^{\prime \prime} \mathrm{W}\end{array}$ & 5 & 22 & 44 \\
\hline
\end{tabular}




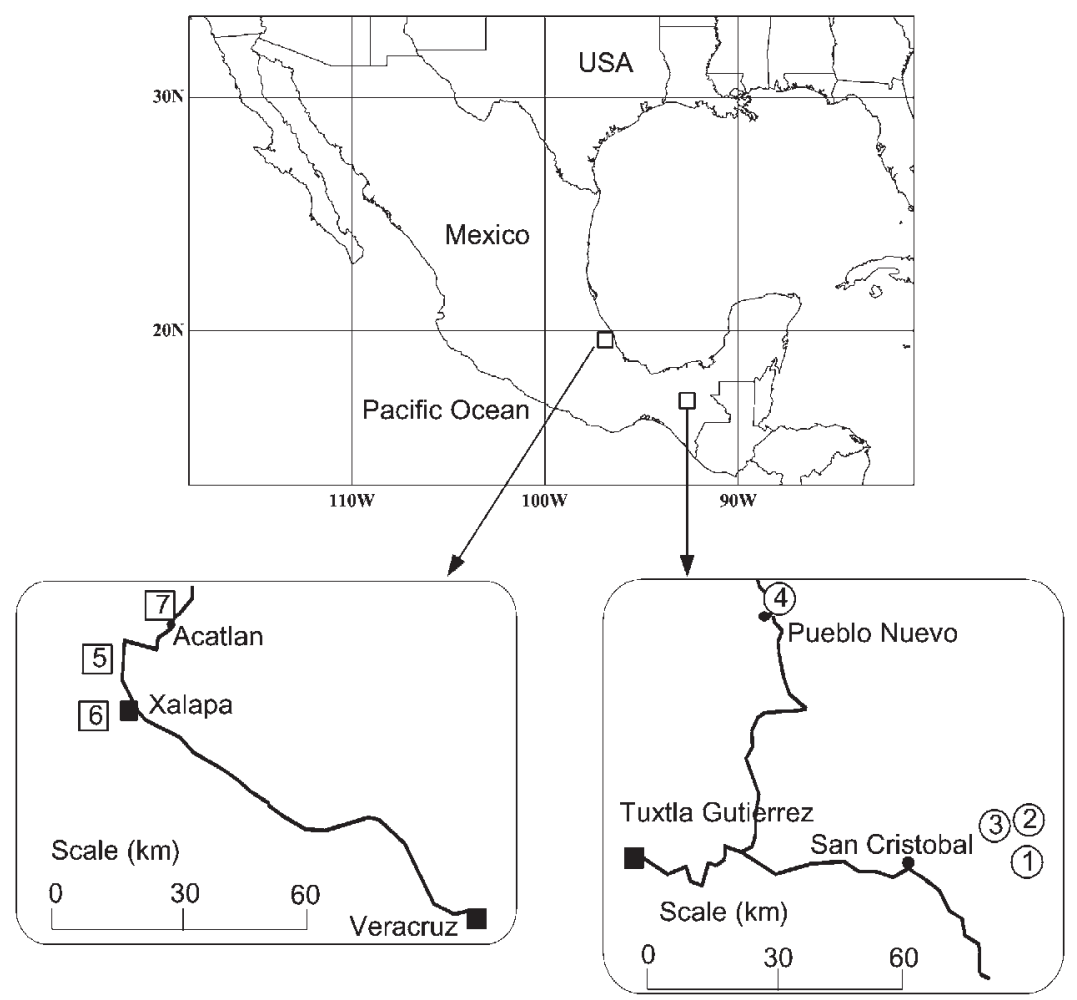

Figure 1. - Distribution of populations of Magnolia sharpii (populations 1-4) and $M$. schiedeana (populations 5-7) included in the genetic analysis.

procedure of the CTAB method, as described previously (AllnUtT et al., 1999).

\section{PCR-RFLP of cpDNA}

A set of six universal primer-pairs was used to amplify non-coding regions of Magnolia chloroplast DNA (c-d and e-f, TABERLET et al., 1991; A, B, E and H, DEMESURE et al., 1995). Analyses of cpDNA were performed on a subsample of four individuals selected at random from the sample population collected from each site.

PCR reaction mixtures ( $20 \mu$ l total volume) contained the following components/concentrations: one unit of Taq DNA polymerase (Bioline), 10x reaction buffer (Bioline), $1.5-3.5 \mathrm{mM} \mathrm{MgCl}{ }_{2}$ (Bioline), $200 \mu \mathrm{M}$ of each dNTP (Sigma), with $0.2 \mu \mathrm{M}$ of each forward and reverse primer and approx. $50 \mathrm{ng}$ of genomic DNA. PCR reactions were carried out in a Perkin-Elmer 480 thermal cycler, in thin-walled $0.6 \mathrm{ml}$ reaction tubes. The following programme was used: 1 step at $94^{\circ} \mathrm{C}$ for $2 \mathrm{~min}$, followed by 35 cycles of $1 \mathrm{~min}$ at $94^{\circ} \mathrm{C}, 1 \mathrm{~min}$ at $50-58^{\circ} \mathrm{C}$, $2 \min$ at $72^{\circ} \mathrm{C}$, and a final $5-7$ min extension step at $72^{\circ} \mathrm{C}$.

Restriction digest reaction mixtures contained the following components: $2 \mu \mathrm{l}$ of restriction enzyme10x reaction buffer (Promega), $2 \mu \mathrm{l}$ of BSA $\left(10 \mathrm{mg} \mathrm{ml}^{-1}\right), 2 \mu \mathrm{l}$ of restriction enzyme $\left(10 \mu \mathrm{g} \mathrm{ll}^{-1}\right), 8 \mu \mathrm{l}$ of DNA (PCR sample), made up to a final volume $20 \mu \mathrm{l}$. Samples were mixed gently by pipetting, centrifuged briefly and incubated overnight at $37^{\circ} \mathrm{C}$ or $65^{\circ} \mathrm{C}$ for Taq I. Restriction digest products were separated by vertical gel electrophoresis using $6 \%$ native polyacrylamide gels, run at $400 \mathrm{v}$ for 1.5 hours.
To identify suitable primer-pair enzyme combinations with the potential to detect chloroplast DNA polymorphism among Magnolia individuals, four individuals of each species were screened with the above primer-pairs. The PCR products were subsequently digested with a set of eight restriction enzymes (Promega Alu I, Cfo I, Rsa I, Hsp92 II, Hae III, Hpa II, Hinf I and nbl Gene Sciences Taq 1).

\section{Inter-SSRs}

Inter-simple sequence repeats (Inter-SSRs) use primers with an anchor short sequence (3-4 base pairs) to amplify variable microsatellites or flanking regions. This method examines random loci in much the same way as RAPDs, but is thought to give more reproducible markers than RAPDs (NEWTON et al., 1999). DNA samples of $80 M$. sharpii individuals sampled from four populations, and of $64 \mathrm{M}$. schiedeana individuals sampled from three populations (Table 1) were analysed using Inter-SSR primers, following the method described by CHARTERs et al. (1996). Sample sizes were limited by the poor quality of the DNA obtained from a small proportion of the leaf samples, and consequently sample sizes were smaller than for the isozyme analysis. 34 InterSSR primers, set 9, obtained from the University of British Columbia were screened for their ability to produce reliable DNA markers. From these, a subset of eight primers $(811,820,834,841,843,849,851$, and 855 ; Table 2) was used to screen $M$. sharpii populations and a subset of seven primers $(811,820,834,836,841$, 843 and 855) was used to screen $M$. schiedeana (Table 2). 
Table 2. - Inter-SSR primer sequences.

\begin{tabular}{ll}
\hline Primer & Sequence \\
\hline 811 & $(\mathrm{GA})_{8} \mathrm{C}$ \\
820 & $(\mathrm{GT})_{8} \mathrm{C}$ \\
834 & $(\mathrm{AG})_{8} \mathrm{YT}$ \\
836 & $(\mathrm{AG})_{8} \mathrm{YA}$ \\
841 & $(\mathrm{GA})_{8} \mathrm{YC}$ \\
843 & $(\mathrm{CT})_{8} \mathrm{YT}$ \\
849 & $(\mathrm{GT})_{8} \mathrm{YA}$ \\
851 & $(\mathrm{GT})_{8} \mathrm{YG}$ \\
855 & $(\mathrm{AC})_{8} \mathrm{YG}$ \\
\hline
\end{tabular}

PCR reaction mixtures $(20 \mu \mathrm{l})$ contained the following components/ concentrations: 1 unit of Taq DNA polymerase (Bioline), $10 \times$ reaction buffer (Bioline), $1.5 \mathrm{mM}$ $\left(\mathrm{MgCl}_{2}\right), 0.2 \mathrm{mM}$ of each dNTP (Sigma), with $0.2 \mu \mathrm{M}$ of each primer and 20-50 ng of DNA. PCR reactions were carried out in a Perkin-Elmer 480 thermal cycler, in thin walled $0.6 \mathrm{ml}$ reaction tubes. The following programme was used: 1 step at $95^{\circ} \mathrm{C}$ for $3 \mathrm{~min}$, followed by 30 cycles of $1 \mathrm{~min}$ at $94^{\circ} \mathrm{C}, 1 \mathrm{~min}$ at $55^{\circ} \mathrm{C}, 1 \mathrm{~min}$ at $72^{\circ} \mathrm{C}$, and a final 5-min extension step of $72^{\circ} \mathrm{C}$. PCR amplification products were separated on $1.5 \%$ agarose gels and visualised by staining with ethidium bromide and photographed over UV light.

PCR products from each primer were scored for each individual and each band was recorded as present (1) or absent (0). These data were entered into a binary matrix and a simple pairwise distance measure was calculated (JACCARD, 1908). These distances were used to perform analysis of molecular variance (AMOVA) (EXCOFFIER et al., 1992). Shannon's diversity estimates (LEWONTIN, 1972) were calculated to provide a relative estimate of the degree of variation within each population according to the formula: $\mathrm{S}=-\Sigma p_{i} \log _{2} p_{i}$, where $p_{i}$ is the frequency of presence or absence of each band (treating each band as a single locus according to LEWONTIN, 1972). $\mathrm{S}_{\mathrm{s}}$ was calculated as the mean value of $\mathrm{S}$ within all of the populations sampled.

\section{Isozyme analyses}

Isozyme analyses were performed following standard procedures (PARKS et al., 1990; CHELIAK and PITEL, 1984). Lithium borate gels with 34.98g:1.74g:270 ml of starch:sucrose:gel by volume, and morpholinecitrate (CN-3-M) gels with 34.99:8.10g:270 $\mathrm{ml}$ of starch:sucrose:gel by volume were used for electrophoresis as these had previously been used successfully with other members of the Magnoliaceae (QUI and PARKS, 1994). Anodal slices of the gels were cut horizontally and activity of the following enzymes was stained for, following the procedures described by SolTis et al. (1983): Asparate aminotransferase (AAT), Phosphoglucose isomerase (PGI), Shikimate dehydrogenase (SDH) and 6Phosphogluconate dehydrogenase (6-PGD). These were selected on the basis that they detected polymorphism during preliminary screening. Knowledge of the monomeric or dimeric structure of these enzymes was used to infer isozyme genotypes from observed banding patterns. Two alleles were detected at each of the loci scored. The FSTAT program (FSTAT 2.9 .3 (2002) J. Goudet, UNIL, Switzerland) was used to estimate Fis, to indicate any deficit or excess of heterozygotes, and to estimate gene diversity for each population.

\section{Results \\ PCR-RFLP of cpDNA}

Samples were amplified with six chloroplast primerpairs; primer-pairs CD, EF (TABERLET et al., 1991) AB, and EH (DEMESURE et al., 1995) produced single bands that were clear, reproducible and suitable for subsequent restriction digest reactions. Restriction digest banding patterns for primer-pairs $\mathrm{EF}$ and $\mathrm{AB}$ were monomorphic for each of the above restriction enzymes. Banding patterns for primer-pairs CD and EH showed polymorphism when digested with restriction $A l u$ I, Hae III, Hinf I Taq 1 Rsa I and Hpa II. On the basis of these results, two chloroplast types were differentiated, denoted types $\mathrm{A}$ and $\mathrm{B}$. Chloroplast type A was recorded

Table 3. - AMOVA analysis of Inter-SSR variation of (A) Magnolia sharpii and (B) Magnolia schiedeana.

\begin{tabular}{|c|c|c|c|c|c|c|}
\hline A & & & & & & \\
\hline & df. & $\begin{array}{l}\text { Sum of } \\
\text { squares }\end{array}$ & $\begin{array}{l}\text { Mean } \\
\text { squares }\end{array}$ & $\begin{array}{l}\text { Variance } \\
\text { component }\end{array}$ & $\begin{array}{l}\% \text { of } \\
\text { total variance }\end{array}$ & $\mathrm{P}$ \\
\hline Among pop. & 3 & 1.89 & 0.63 & 0.02 & 10.58 & 0.002 \\
\hline Within pop. & 76 & 14.34 & 0.19 & 0.19 & 89.42 & \\
\hline \multicolumn{7}{|l|}{ B } \\
\hline & df. & $\begin{array}{l}\text { Sum of } \\
\text { squares }\end{array}$ & $\begin{array}{l}\text { Mean } \\
\text { squares }\end{array}$ & $\begin{array}{l}\text { Variance } \\
\text { component }\end{array}$ & $\begin{array}{l}\% \text { of } \\
\text { total variance }\end{array}$ & $\mathrm{P}$ \\
\hline Among pop. & 2 & 3.12 & 1.56 & 0.06 & 25.68 & 0.002 \\
\hline Within pop. & 61 & 11.38 & 0.18 & 0.19 & 74.32 & \\
\hline
\end{tabular}


for all of the individuals of both species with the exception of population 6 (M. schiedeana), which was fixed for chloroplast type B.

\section{Inter-SSRs}

A total of 20 polymorphic bands were scored for M. sharpii. From these 20 bands a total of 79 genotypes was recognised with individuals 7 and 24 sharing the same banding pattern. For M. schiedeana a total of 17 polymorphic bands were scored and from these bands a total of 53 genotypes were recorded with individuals 5 and $6 ; 15$ and $22 ; 29$ and $37 ; 31$ and $40 ; 46,54$, and 63 ; 47 and $64 ; 48,51,58$ and $61 ; 52$ and 59 each sharing the same banding pattern.

The results of the AMOVA for $M$. sharpii showed that most of the genetic variation was found within populations $(89 \%$, Table $3 a)$. However, a significant proportion $(11 \%, \mathrm{P}<0.002)$ was attributed to differences among populations. All populations differed significantly from each other $(\mathrm{P}<0.05)$, with the exception of populations 1 and 3 , with the highest pairwise $\Phi_{\mathrm{ST}}$ value (0.21) recorded between populations 1 and 4. For M. schiedeana, 74\% of the genetic variation was found within populations and $26 \%$ found among populations $(\mathrm{P}<0.002)$ (Table $3 b$ ). All populations were significantly different from each other $(\mathrm{P}<0.05)$, with the highest pairwise $\Phi_{\text {ST }}$ value (0.30) recorded between populations 5 and 7 .

The relative diversity within each $M$. sharpii population, as measured by Shannon's index, was calculated as 0.50 for population $1,0.53$ for population $2,0.69$ for population 3 and 0.49 for population 4 , with a mean $\mathrm{S}_{\mathrm{s}}$ of 0.56. For $M$. schiedeana populations, values of Shannon's index were recorded as 0.59 for population $5,0.65$ for population 6 and 0.34 for population 7 , with a mean $\mathrm{S}_{\mathrm{s}}$ of 0.50 .

\section{Isozymes}

All of the resolved putative isozyme loci were polymorphic in all of the populations, with two alleles recorded per locus in each case. Allele frequencies differed markedly between populations; for example, for PGI-1 frequencies of allele A ranged from 0.33 (population 2) to 0.74 (population 5 ). In the case of 6 PGD-1, frequencies of allele A for populations of $M$. sharpii ranged from 0.5-0.6; those recorded for $M$. schiedeana displayed a much wider range, from 0.25 (population 5) to 0.94 (population 6). Frequencies of SDH-1 displayed little variation between populations, values for allele A ranging from 0.52 (population 7) to 0.72 (population 5). In the case of AAT-1, populations 1 and 2 displayed relatively low frequencies of allele $\mathrm{A}$ ( 0.26 and 0.375 respectively); all other values were above 0.65 . In general, populations 3 and 4 displayed similar allele frequencies, whereas population 5 displayed a markedly different profile of allele frequencies than the other populations sampled.

Estimates of $\mathrm{F}_{\text {is }}$ based on isozyme data indicate that all populations of $M$. sharpii have an excess of heterozygotes $\left(\mathrm{F}_{\text {is }}\right.$ values very negative), providing some evidence of inbreeding (Table 4). The $\mathrm{F}_{\text {is }}$ value for population 5 of $M$. schiedeana also provided some evidence of inbreeding; other populations of this species were close to ran-
Table 4. - Estimates of $\mathrm{F}_{\text {is }}$ and gene diversity for populations of (A) Magnolia sharpii and (B) M. schiedeana, based on isozyme data. For methods of calculation, see text. For details of populations, see Table 1.

\begin{tabular}{lllll}
\hline $\begin{array}{l}\text { A. } M \text {. sharpii } \\
\text { (i) } \mathrm{F}_{\text {is }} \text { per population }\end{array}$ & \multicolumn{5}{c}{} \\
& \multicolumn{5}{c}{ Population number } & & \\
& 1 & 2 & 3 & 4 \\
PGI-1 & 0.06 & 0.27 & -0.32 & 0.19 \\
6PGD-1 & -0.68 & -1.00 & -0.86 & -0.68 \\
SDH-1 & -0.40 & -0.22 & -0.59 & -0.25 \\
AAT-1 & 0.12 & 0.18 & -0.49 & 0.03 \\
All & -0.23 & -0.21 & -0.57 & -0.17 \\
\hline
\end{tabular}

(ii) Expected heterozygosity (gene diversity)

\begin{tabular}{lllll} 
& 1 & 2 & 3 & 4 \\
PGI-1 & 0.49 & 0.45 & 0.49 & 0.51 \\
6PGD-1 & 0.49 & 0.50 & 0.50 & 0.49 \\
SDH-1 & 0.43 & 0.43 & 0.47 & 0.40 \\
AAT-1 & 0.39 & 0.48 & 0.45 & 0.46 \\
& & & & \\
Mean & 0.451 & 0.46 & 0.478 & 0.46 \\
$95 \% \mathrm{CI}$ & 0.046 & 0.03 & 0.022 & 0.05 \\
\hline
\end{tabular}

(B). M.shiedeana

(i) Fis per population:

\begin{tabular}{llll} 
& \multicolumn{3}{c}{ Population number } \\
& 5 & 6 & 7 \\
PGI-1 & -0.33 & 0.30 & 0.286 \\
6PGD-1 & 0.63 & 0.66 & 0.138 \\
SDH-1 & -0.35 & -0.26 & -0.457 \\
AAT-1 & -0.14 & -0.23 & 0.161 \\
All & -0.05 & 0.01 & 0.003 \\
\hline
\end{tabular}

(ii) Gene diversity per locus and population:

\begin{tabular}{llll} 
& 5 & 6 & 7 \\
PGI-1 & 0.39 & 0.46 & 0.50 \\
6PGD-1 & 0.39 & 0.11 & 0.26 \\
SDH-1 & 0.40 & 0.45 & 0.51 \\
AAT-1 & 0.38 & 0.32 & 0.35 \\
& & & \\
Mean & 0.39 & 0.33 & 0.40 \\
95\%CI & 0.01 & 0.16 & 0.12 \\
\hline
\end{tabular}

dom mating ( $F_{\text {is }}$ values close to 0 ). Estimates of $G_{\text {st }}$ based on isozyme data provided values of 0.034 and 0.129 for $M$. sharpii and $M$. schiedeana respectively, indicating a higher degree of population differentiation within the latter species. Estimates of gene diversity highlighted little difference between populations of either species, although values recorded for $M$. sharpii tended to be higher than those recorded for $M$. schiedeana (Table 4).

\section{Discussion}

As both $M$. sharpii and $M$. schiedeana are endemic species with restricted ranges, we hypothesized that both species would display relatively low genetic variation overall. However, the current results do not support this contention. Measures of the extent of within-population variation assessed using the Inter-SSR markers (mean $\mathrm{S}_{\text {pop }}$ of 0.56 and 0.50 for $M$. sharpii and $M$. schiedeana respectively) are comparable to values obtained for other tree species using RAPD markers, for 
example 0.54 for Pinus chiapensis (NEWTON et al., 2002), 0.57 for Pilgerodendron uviferum (ALLNUTT et al., 2003), 0.43 for Cedrela odorata (GILliEs et al., 1997), 0.55 for Fitzroya cupressoides (AllnUTT et al., 1999), 0.65 for Araucaria araucana (BEKESSY et al., 2002) and 0.36 for Swietenia macrophylla (GILLIEs et al., 1999). Interestingly, the value recorded for Fagus grandiflora var. mexicana, another endemic Mexican tree restricted to cloud forests, was substantially lower (0.20) (ROwDEN et al., 2004).

As noted by NYBOM and BARTISH (2000), a number of studies have reported relatively high within-population genetic diversity for endemic plant taxa, suggesting that some species are able to maintain relatively high genetic variability despite the higher risk of genetic drift and inbreeding in small, isolated populations. The current results suggest that this may be the case for the Magnolia species studied here. However, measures of withinpopulation variation in both species appeared to be unrelated either to the size or to the degree of isolation of the forest fragment. These results contrast markedly with those obtained for Fagus grandiflora var. mexicana, where within-population variation was found to be significantly correlated with population size (RowDEN et al., 2004).

Based on the review of NYBOM and BARTISH (2000), we expected that $M$. sharpii would be characterised by a lower degree of population differentiation than $M$. schiedeana, given that the latter species has a substantially wider geographic range. Based on the results of the isozyme analysis, the degree of population differentiation recorded here within $M$. schiedeana (12.9\%) appears to be typical for a species with its ecological characteristics. A review of isozyme studies undertaken with 73 woody species of angiosperm indicated that on average, $10.2 \%$ of genetic variation was recorded between rather than within populations; when endemic species were considered as a group, a mean value of $14.1 \%$ was recorded (HAMRICK et al., 1992). The mean value for woody species with a mixed-animal breeding system was $12.2 \%$ (HAMRICK et al., 1992). In contrast, the extent of population differentiation recorded here within $M$. sharpii was relatively low (3.4\%). Values of population differentiation recorded using Inter-SSR markers were consistent with these results, with lower values recorded for $M$. sharpii than $M$. schiedeana, supporting our initial hypothesis ( $11 \%$ and $26 \%$ for the two species respectively).

This finding supports the findings of NYBOM and BARTISH (2000), as the species with wider geographic range exhibited higher differentiation among populations. However, the results contrast with the conclusions of HAMRICK et al. (1992). In particular, the low degree of population differentiation recorded for $M$. sharpii is surprising. This implies that gene flow is occurring between populations of the species, or has occurred in the past, despite the fragmented nature of the landscapes in which they occur. However, the results from the isozyme analysis provide some evidence for possible inbreeding in this species, based on the presumed removal of homozygotic individuals. In the absence of information about the mating system or investigations of controlled crosses, the evidence of inbreeding must be considered as tentative. Very little is known about the ecology of $M$. sharpii; it is conceivable that it is dependent on specialised beetles for pollination, as recorded for M. schiedeana (DIERINGER and ESPINOSA, 1994), but this is unknown at present. Alternatively, as the seeds are bird-dispersed, it is conceivable that gene flow between forest fragments is occurring through movement of seed dispersal vectors. Recent assessments of size structure distribution suggest that populations of $M$. sharpii are regenerating (RAMÍREZ-MARCIAL et al., 2001), but the germinability of seeds appears to be very variable (N. RAMÍREZ-MARCIAL, personal observation). Research into patterns of gene flow in two Japanese Magnolia species using microsatellite markers has recorded pollen movement over distances of $540 \mathrm{~m}$, and long-distance gene flow resulting from bird dispersal, but has also recorded inbreeding depression as a result of differences in flowering phenology (IsAGI et al., 2000), and a high degree of population differentiation in one species (KIKUCHI and IsAGI, 2002), as recorded here.

Isozyme analyses provide less evidence for inbreeding within M. schiedeana. However, the degree of population differentiation recorded here for this species using InterSSR markers is exceptionally high compared to studies of other tree species using similar approaches. For example, the $\Phi_{\mathrm{ST}}$ value recorded here (0.26) was substantially higher than values derived from RAPD analysis of wind-pollinated trees Araucaria araucana (0.13, BeKessy et al., 2002), Fitzroya cupressoides (0.14, ALLNUTT et al., 1999), Podocarpus salignus (0.07, ALLNUTT et al., 2001), Pilgerodendron uviferum (0.19, AllnutT et al., 2003), Pinus chiapensis (0.23, NEWTON et al., 2002) and Fagus grandifolia var. mexicana (0.16, RowDEN et $a l ., 2004)$. This result implies limited gene flow between populations of $M$. schiedeana, either currently or historically.

A particularly noteable result was the cpDNA polymorphism recorded for $M$. schiedeana in Acatlán. The occurrence of a cpDNA polymorphism within such a small geographic area contrasts with results from widespread tree species; for example in 64 populations of Liriodendron tulipifera (Magnoliaceae) distributed throughout the eastern USA, only two cpDNA haplotypes were recorded (SEwELl et al., 1996). Similarly in European beech (Fagus sylvatica), much of central Europe was found to be dominated by a single cpDNA haplotype, interpreted as indicating postglacial recolonization from a single forest refugium in south-east Europe (DEMESURE et al., 1996). Intriguingly, one of the three haplotypes recorded for another endemic tree, Mexican beech (Fagus grandiflora var. mexicana), was also found in Acatlán (RowDEN et al., 2004). This result, coupled with the high degree of population differentiation recorded by Inter-SSR markers suggests that the $M$. schiedeana populations studied here may have distinct biogeographic histories, despite their relatively close proximity.

The pronounced climatic changes experienced in Mexico during the Holocene (from around 8500-9000 yr BP) 
had a major impact on forest distribution and composition (HEINE and OHNGEMACH, 1976), and may have led to the fragmentation and restriction of the cloud forests in which Magnolia currently occurs. Mexican cloud forests, which are today fragmented throughout their range, are remnants of a 'temperate rain forest' that extended to the eastern United States during the early Tertiary (GRAHAM, 1973; 1976). Those populations characterised by different cpDNA haplotypes may have been isolated for a substantial period of time (ENNOS et al., 1999). However, further analyses are required to test this hypothesis more fully.

Given their complex biogeographic history, the relative impacts of recent human activities on genetic variation in these species are difficult to elucidate. The cloud forest habitat in which both $M$. sharpii and $M$. schiedeana occur is undoubtedly under severe pressure, primarily from clearance for agriculture (WiLliams-LinERA, 2002; NEWTON, 2007). Recent observations in the Chiapan cloud forests in which $M$. sharpii occurs suggest that floristic diversity is declining rapidly as a result of frequent, small-scale anthropogenic disturbance (RAMíREZ-MARCIAL et al., 2001; GALINDO-JAIMES et al., 2002; NEWTON, 2007). A similar situation prevails in the forests in Veracruz where $M$. schiedeana occurs (WILLIAMS-LinERA, 2002). As both species now appear to be severely restricted in distribution, they both must be considered at severe risk of extinction, and as high priorities for conservation action.

The analyses of genetic variation presented here could inform the development of conservation strategies by assisting in the definition of appropriate units for conservation, as proposed for other tree species (NEWTON et al., 1999). The fact that significant genetic differences were recorded here between most of the populations studied suggests that most, if not all, of the remaining populations of these species should be afforded protection in order to adequately conserve the full range of intraspecific variation that exists. Future research might usefully focus on confirming whether or not inbreeding is occurring within the species, and estimating current rates of gene flow in these species using microsatellite markers (ISAGI et al., 2000; KIKUCHI and ISAGI, 2002), enabling the relationship between current patterns of land use and the viability of fragmented populations to be analysed.

\section{Acknowledgements}

The research was funded by the European Commission as part of the SUCRE Project (ERBIC18CT970146) and the BIOCORES project (ICA4-CT-2001-10095). ALFONSO Luna-Gómez, Miguel Martínez-Icó and Fausto BolomTON assisted with collection of $M$. sharpii; ClAUdIA Alvarez-Aquino and Rosa Amelia Pedraza assisted with collecting $M$. schiedeana. J. Gow was supported by a NERC postgraduate studentship; and the Davis Expedition Fund, the Small Project Grant, the British Associate Travel Fund, and the Student Travel Fund of the University of Edinburgh. SUE MCAUlEY of Glasgow University assisted with DNA sequencing. We are very grateful to colleagues at IERM, University of Edinburgh for helpful discussions.

\section{References}

Allnutt, T. R., A. C. Newton, A. Lara, A. Premoli, J. J. Armesto, R. Vergara and M. Gardner (1999): Genetic variation in Fitzroya cupressoides (alerce), a threatened South American conifer. Molecular Ecology 8: 975-987.

Allnutt, T. R., J. R. Courtis, M. Gardner and A. C. NewTON (2001): Genetic variation in wild Chilean and cultivated British populations of Podocarpus salignus D. Don (Podocarpaceae). Edinburgh Journal of Botany 58(3): 459-473.

Allnutt, T. R., A. C. Newton, A. Premoli and A. Lara (2003): Genetic variation in the threatened South American conifer Pilgerodendron uviferum (Cupressaceae), detected using RAPD markers. Biological Conservation 114: 245-253.

Bekessy, S. A., T. R. Allnutt, A. C. Premoli, A. Lara, R. A. Ennos, M. A. Burgman, M. Cortes and A. C. NewTON (2002): Genetic variation in the vulnerable and endemic Monkey Puzzle tree, detected using RAPDs. Heredity 88: 243-249.

Callaway, D. J. (1994): Magnolias. London: BT Batsford Ltd.

Cascante, A., M. Quesada, J. J. Lobo and E. A. Fuchs (2002): Effects of dry tropical forest fragmentation on the reproductive success and genetic structure of the tree Samanea saman. Conservation Biology 16: 137-147.

Cayuela, L., J. M. Rey Benayas and C. Echeverria (2006): Clearance and fragmentation of tropical montane forests in the Highlands of Chiapas, Mexico (1975-2000). Forest Ecology and Management 226: 208-218.

Charters, Y. M., A. Robertson, M. J. Wilkinson and G. RAMSAY (1996): PCR analysis of oilseed rape cultivars (Brassica napus L. ssp. oleifera) using 5' anchored simple sequence repeat (SSR) primers. Theoretical and Applied Genetics 92: 442-447.

Cheliak, W. M. and J. A. Pitel (1984): Techniques for Starch Gel Electrophoresis of Enzymes from Forest Tree Species. Canadian Forestry Service, Petawawa National Forestry Institute, Information report D1-X42. Pp. 1-49.

Cicuzza, D., A. C. Newton and S. Oldfield (2007): The Red List of Magnoliaceae. Fauna and Flora International, Cambridge, UK.

DANDY, J. E. (1971): The classification of Magnoliaceae. Newsletter of the American Magnolia Society 8: 3-6.

Demesure, B., B. Comps and R. J. Petit (1996): Chloroplast DNA phylogeography of the common beech (Fagus sylvatica L.) in Europe. Evolution 50: 2515-2520.

Demesure, B., N. Sodzi and R. J. Petit (1995): A set of universal primers for amplification of polymorphic noncoding regions of mitochondrial and chloroplast DNA in plants. Molecular Ecology 4: 129-131.

DiERINGER, G. and L. DELGADo (1994): Notes on the biology of Cyclocephala jalapensis (Coleoptera: Scarabaeidae): an endemic of eastern Mexico. Southwestern Entomologist Scientific Note 19: 309-311.

Dieringer, G. and J. E. Espinosa (1994): Reproductive ecology of Magnolia schiedeana (Magnoliaceae), a threatened cloud forest tree species in Veracruz, Mexico. Bulletin of the Torrey Botanical Club 121: 154-159.

EnNos, R. A., W. T. Sinclair, X. S. Hu and A. LANGdon (1999): Using organelle markers to elucidate the history, ecology and evolution of plant populations. In: Hollingsworth, P. M., Bateman, R. M., Gornall, R. J., 
eds. Molecular Systematics and Plant Evolution, 1-19. London: Taylor and Francis.

Excoffier, L., P. E. Smouse and J. M. QuatTro (1992): Analysis of molecular variance inferred from metric distances among DNA haplotypes: application to human mitochondrial DNA restriction data. Genetics 131: 479-491.

FiglaR, R. B. (1993): Stone magnolias. Arnoldia 53: 2-9.

Frodin, D. G. and R. GovaerTs (1996): World Checklist and Bibliography of Magnoliceae. Richmond: The Board of Trustees of the Royal Botanic Gardens, Kew.

Galindo-Jaimes, L., M. GonzÁlez-Espinosa, P. QuintanaASCENCIO and L. GARCÍA-BARRIOS (2002): Tree composition and structure in disturbed stands with varying dominance by Pinus spp. in the highlands of Chiapas, México. Plant Ecology 162: 259-272.

Gillies, A. C. M., J. P. Cornelius, A. C. Newton, C. Navarro, M. Hernández and J. Wilson (1997): Genetic variation in Costa Rican populations of the tropical timber species Cedrela odorata L., assessed using RAPDs. Molecular Ecology 6: 1133-1145.

Gillies, A. C. M., C. Navarro, A. J. Lowe, A. C. Newton, M. Hernández, J. Wilson and J. P. CoRnelius (1999): Genetic diversity in Mesoamerican populations of mahogany (Swietenia macrophylla), assessed using RAPDs. Heredity 83: 722-732.

GitzendanneR, M. A. and P. S. Soltis (2000): Patterns of genetic variation in rare and widespread plant congeners. American Journal of Botany 87: 783-792.

GonZÁlez-Espinosa, M., S. OChOA-GaOnA, N. RAMíreZMARCIAL and P. F. QUINTANA-AsCENCIO (1995): Current land-use trends and conservation of old-growth forest habitats in the highlands of Chiapas, México. In: WILSON, M., SADER, S. eds. Conservation of Neotropical Migratory Birds in Mexico, 190-198. Orono, Maine: Maine Agricultural and Forest Experiment Station, Miscellaneous publication 727.

GonZÁlez-Espinosa, M., P. F. Quintana-Ascencio, N. RAMírEZ-MARCIAL and P. GAYTÁN-GuZMáN (1991): Secondary succession in disturbed Pinus-Quercus forests in the highlands of Chiapas, Mexico. Journal of Vegetation Science 2: 351-360.

GRAHAM, A. (1973): History of the arborescent temperate element in the northern Latin American biota. In: GRAHAM, A. ed. Vegetation and Vegetational History of Northern Latin America, 301-314. Amsterdam: Elsevier.

GRAHAM, A. (1976): Studies in neotropical paleobotany II. The Miocene communities of Veracruz, Mexico. Annals of the Missouri Botanic Garden 63: 787-842.

Hamrick, J. L., M. J. W. GodT and S. L. Sherman-Broyles (1992): Factors influencing levels of genetic diversity in woody plant species. New Forests 6: 95-124.

HEINE, K. and D. OHNGEMACH (1976): Die Pleistozän/ Holozän-Grenze in Mexiko. Münstersche Forschungen zur Geologie und Paläonontologie 38/39: 229-251.

Isagi, Y., T. Kanazashi, W. Suzuki, H. TAnaka and T. Abe (2000): Microsatellite analysis of the regeneration process of Magnolia obovata Thunb. Heredity 84(2): 143-151.

JACCARD, P. (1908): Nouvelles recherches sur la distribution florale. Bulletin, Societe Vaudoise des Sciences Naturelles 44: 223-270.

KIKUCHI, S. and Y. ISAGI (2002): Microsatellite genetic variation in small and isolated populations of Magnolia sieboldii ssp. japonica Heredity 88: 313-321.
Lewontin, R. C. (1972): The apportionment of human diversity. Evolutionary Biology 6: 381-398.

NASON, J. D. and J. L. HAMrICK (1997): Reproductive and genetic consequences of forest fragmentation: two case studies of neotropical canopy trees. Journal of Heredity 88: $264-76$.

Newton, A. C. (Ed.) (2007) Biodiversity Loss and Conservation in Fragmented Forest Landscapes. Evidence from Tropical Montane and South Temperate Rain Forests in Latin America. CABI Publishing, Wallingford, Oxford, UK.

Newton, A. C., T. Allnutt, A. C. M. Gillies, A. Lowe and R. A. EnNos (1999): Molecular phylogeography, intraspecific variation and the conservation of tree species. Trends in Ecology and Evolution 14(4): 140-145.

Newton, A. C., T. R. Allnutt, W. Dvorak, R. Del Castillo and R. EnNos (2002): Patterns of genetic variation in Pinus chiapensis, a threatened Mexican pine, detected by RAPD and mitochondrial DNA RFLP markers. Heredity 89: 191-198.

NyBOM, H. and I. V. BARTisH (2000): Effects of life history traits and sampling strategies on genetic diversity estimates obtained with RAPD markers in plants. Perspectives in Plant Ecology, Evolution and Systematics 3/2: 93-114.

PARKS, C. R. and J. F. WENDEL (1990): Molecular divergence between Asian and North American species of Liriodendron (Magnoliaceae) and implications for interpretation of fossil floras. American Journal of Botany 77: $1243-1256$.

Premoli, A. C., C. P. Souto, T. R. Allnutt and A. C. NewTON (2001): Effects of population disjunction on isozyme variation in the widespread Pilgerodendron uviferum. Heredity 87(3): 337-343.

QUI, Y. L. and C. R. PARKS (1994): Disparity of allozyme variation levels in three Magnolia (Magnoliaceae) species from the southeastern United States. American Journal of Botany 81: 1300-1308.

RAMíreZ-MARCIAL, N., M. GONZÁlEZ-EsPinOSA and G. Williams-LiNERA (2001): Anthropogenic disturbance and tree diversity in montane rain forests in Chiapas, Mexico. Forest Ecology and Management 154 (1-2): 311-326.

Rowden, A., A. Robertson, T. R. Allnutt, S. Heredia, G. Williams-Linera and A. C. Newton (2004): Conservation genetics of Mexican beech, Fagus grandifolia var. mexicana. Conservation Genetics 5 (4): 475-484.

Sewell, M. M., C. R. Parks and M. W. Chase (1996): Intraspecific chloroplast DNA variation and biogeography of north American Liriodendron L. (Magnoliaceae). Evolution 50(3): 1147-1154.

Soltis, D. E., C. H. Haufler, D. C. Darrow and G. J. GASTONY (1983): Starch gel electrophoresis of ferns: a compilation of grinding buffers, and staining schedules. American Fern Journal 73: 9-27.

Taberlet, P., L. Gielly, G. Pautou and J. Bouvet (1991): Universal primers of three non-coding regions of chloroplast DNA. Plant Molecular Biology 17: 1105-1109.

VÁZQUEZ, J. A. (1994): Magnolia (Magnoliaceae) in Mexico and Central America: a synopsis. Brittonia 46: 1-23.

WilliAMS-LineRA, G. (2002): Tree species richness complementarity, disturbance and fragmentation in a Mexican tropical montane cloud forest. Biodiversity and Conservation 11 (10): 1825-1843. 